\title{
Tumor Necrosis Factor Receptor Superfamily Member 19
}

National Cancer Institute

\section{Source}

National Cancer Institute. Tumor Necrosis Factor Receptor Superfamily Member 19. NCI

Thesaurus. Code C159406.

Tumor necrosis factor receptor superfamily member 19 (423 aa, $46 \mathrm{kDa}$ ) is encoded by the human TNFRSF19 gene. This protein is involved in the activation of both the JNK pathway and caspase-independent cell death. 